\title{
PÖIDE VALLA KOHANIMEDE MUUTUMINE
}

\author{
MARIT ALAS
}

\section{Sissejuhatus}

\begin{abstract}
A rtikkel põhineb 2008. aastal Tallinna Ülikoolis kaitstud magistritööl (Alas 2008b), mille eesmärk oli anda ülevaade kohanimede muutumist puudutavast teooriast ning uurida nimede muutumist, et teada saada, kui suur ja milline osa nimedest on viimasel kolmel sajandil säilinud või muutunud. Kolme andmekogu võrdluses on vaadeldud nii lingvistilisi kui ka ekstralingvistilisi tegureid ja tegurikimpe, mis on kohanimede muutumist põhjustanud või suunanud. Kohanimede muutumise uurimisega on Eestis vähe tegeldud (vt Simm 1971; 1976), selline kohanimede säilimist, tekkimist, vahetumist ning kadu puudutav sotsioonomastiline uurimus on eesti onomastikas esmakordne. Selle uurimuse põhjal on võimalik näha Pöide nimevara praegust seisu ning suhet varasemate nimekogudega. Samuti on uus suund, mis ei uuri kohanimede muutumist nime ajaloost lähtuvalt, vaid keskendub konkreetse koha nime muutustele (Alas 2009a: 40; 2009c: 68). Pöide valla 1787. aasta materjal (367 nime) on saadud Eesti Ajalooarhiivi saksakeelsest kaardiatlasest, 1 1933. aasta nimed (1921 kohanime) Eesti Keele Instituudist Theodor Kaljo materjalikogust. Autori materjal (1397 nime) on kogutud Pöide vallas aastatel 2004-2007. Kolmest ajajärgust on erinevaid toponüüme kokku $2911 .^{2}$

Pöide piirkonnas on põllumajandusega tegeldud rohkem sisemaal, rannaäärsetel aladel on peamiseks elatusallikaks olnud kalastamine. Saarlastel on siiani säilinud oma murre ning tugev kohaga seotud identiteet, mida saarelisus oma piiratud territooriumiga on tugevdanud. Asustus on küllaltki tihe, suurimaks asustusüksuseks on küla. Tüübilt on need kas sumbkülad või sumbja tuumaga ridakülad: talud on tihedalt koos, põllumaad külast eemal. Elanikke on vallas ligi tuhat (suviti arv mitmekordistub) ning talusid 30 küla peale umbes viissada. Piirkonna kohanimed jagunevad laias laastus kaheks. Merega kolmest küljest ümbritsetus ning väga liigendatud rannaäär on and-
\end{abstract}

1 f 2072, n 3, s 462 d.

2 Arvudest nähtub, et XVIII sajandi lõpu materjal on kõige väikesem (10\%). Uurimuses kasutatud atlases ning üldse tolleaegsetel kaartidel on väga vähe talunimesid, märgitud on vaid hajatalude nimed. Asulanimed on saksakeelsed ning põhirõhk on põllumajanduslikel kohtadel, mille hulgast on harva välja toodud väikesemate üksuste nimesid (näiteks põllu-, heinamaa- ning karjamaaosade nimesid). Loodusnimesid on vähem, märgitud on need üldjuhul siis, kui sinna jääb ka mingi põllumajanduslik ala (näiteks laiul on ka heinamaaks sobivat maad). Et atlase eesmärk on kajastada põllumajandusobjektide nimesid, on küla-, hajatalude ning loodusnimed esitatud pigem viljeluskohtade asukoha määramiseks. 1933. aasta materjal (52\%) on neist kolmest vaadeldavast ajast kõige põhjalikum, sest siis oli veel väga palju väikeseid vabadikukohti, mis on tänaseks ühes nimedega hävinud. Samuti on põllumajanduslikud, aga ka looduslikud objektid jaotatud väga väikesteks osadeks, hõlmates sageli vaid ühe talu kasutusse kuuluvaid kohanimesid. Tänapäevase materjali $(38 \%)$ iseloomuks on pigem viljelusnimede ning mikrotoponüümide väiksem osakaal. Säilinud on suuremate kohtade nimed, mille väikesemate osade tähistajaid enam ei teata. 
nud aluse loodusnimede domineerivusele, sisemaale jäävad põllumajanduslikud alad on tinginud aga kultuurnimede rohkuse. Loodusnimed on oma loomult püsivamad, sest ka nende denotaadid on looduses pikaealisemad kui inimtegevuse tagajärjel tekkinud kohad. Kogu piirkond moodustab aga ühe kultuurilise terviku, kus on homogeenne rahvastik ning ühine ajalugu (Alas 2009b: 76).

\section{Kohanimede muutumine}

Kohanime muutuste all pean silmas kohanime tekkimist (uue koha aktuaalseks muutumisel antakse kohale oma nimi, et seda teistest eristada), vahetumist (täieliku muutuse puhul on nimi vahetunud leksikaalselt täielikult, osalise muutuse korral on vahetunud determinant või osa atribuudist) ja kadumist (nime enam ei kasutata) (vt ka Ainiala 1997b: 108-113).

\subsection{Kohanimede tekkimine ja säilimine}

Kohanimed on kui minitekstid, millel on tähendus, ja nad on seotud konnotatiivsete ja assotsiatiivsete komponentidega rohkem kui denotatiivsetega (Christoph 1990: 232). Nimed ei teki juhuslikult, vaid on kas või mingil ajahetkel olnud põhjuslikus seoses nimetatud kohaga. Kuigi kohtade maastikus eristamine on toimunud algselt koha kirjeldamise teel (Nissilä 1962: 39), ei ole kohanime eesmärk kohta kirjeldada, vaid seda teistest samaliigilistest kohtadest eristada, individualiseerida (Dalberg 2008: 51; Kallasmaa 2000: 73). Toponüümid tekivad siis, kui inimestel on vaja nimetada kohti, mida nad kasutavad või muul moel oluliseks peavad. Eero Kiviniemi on väitnud, et kohanimede vajadus sõltub ainuüksi kommunikatsioonitarbest ja et eriti mikrotoponüümide puhul sõltub nimetihedus asustustihedusest ja nimeoskus individuaalsetest kommunikatsioonivajadustest (Kiviniemi 1990: 99). Kohanimede abil saab kohti meeles pidada ning neist teistele rääkida. Igal geograafilisel üksusel ei pruugi olla nime, küll aga kuulub iga kohanime juurde asukoht, millele ta viitab, ning tähendus, mida see nimi kannab.

Nimede tekke suureks mõjutajaks on pigem ühiskondlikud muutused, mitte niivõrd looduslikud varieerumised. Looduses toimuvad arengud üldjuhul aeglaselt, see-eest inimeste endi põhjustatud ümberkorraldused tekitavad uusi kohti ja omakorda uusi nimesid kiiremini. Palju nimesid on lisandunud (aga ka kadunud) nõukogudeaegse maade ümberjaotamise käigus: see aeg on viimase kolme sajandi murrangulisim ning põhjustanud järske ja rohkeid kohanimemuudatusi. Väikeste talupõldude suurteks kolhoosipõldudeks liitmisel kadusid väikeste põldude nimed. Uusi suurpõlde nimetati näiteks küla järgi (Nenu põllud) või talu järgi (Tõnutagune). Ehitati uued kolhoosilaudad, nt Kalmemäe laut, Kanissaare laut ja Seljamäe laut; tekkisid uued kohad, nagu Side (postkontor), Eliladu (õli- ehk kütuseladu) ning Kontor $\sim$ Kolhoosikontor.

Kui koha laad muutub, võib nimi jääda samaks, ent siis peab ta suutma seda kohta endiselt identifitseerida. Pöide aladelt võib selliselt säilinud nimesid leida vaid üksikuid. Näiteks kunagine merepõhi oli kasutusel esmalt karjamaana, seejärel heinamaana, nüüd aga põldudena, kuid see on siiski säilitanud oma algse nime Rooga laht. Ka nimed Aabelaskma ja Jausapõllud on 
säilinud samana läbi kolme sajandi, kuid nende denotaatide kasutamine on aja jooksul varieerunud. Pigem on säilinud selliste kohtade nimed, mis kasutaja jaoks ei anna enam edasi denotaadi kasutusala või mille determinant on lihtsasti nimest väljajäetav ning atribuut esineb ka teiste sealsete kohtade nimes, moodustades ühtse kimbu. Näiteks võib tuua nime Sansa Meggi Pöld, mis on XVIII sajandi kaardil ainus selle atribuudiga nimi. 1933. aastaks on põllust saanud Santsesilmaesine heinamaa, lisaks leiab 1933. aasta ja tänapäeva materjalist Santse mäe, 1933. aastal oli seal ka Santse asundustalu. Tänapäeval on vaadeldav koht osa suuremast Santse piirkonnast ning sama täiendiga on nii 1933. kui ka 2007. aastal olemas rannajärv Santse lõpp.

Nimetamine pole osa igapäevakeelest, nagu seda on vestlus, vaid põhineb suhteliselt tugevalt juba olemasolevate nimede analoogial (Leino 2007: 13). Nimeandja ei anna nime meelevaldselt, vaid kasutab tuttavaid mudeleid. Sarnaselt 1933. aastal olemas olnud Ardla soole on tänapäevaks loodud kõrval asuva vesise heinamaa nimi Välta soo, kasutades samuti küla nime, mille alale heinamaa kuulub. Üleüldine tendents kasutada analoogiat eksisteerib isegi nimede puhul, mis on selgelt seotud koha füüsilise iseloomuga (Leino 2007: 97). Näiteks kahel pool laidu asuvate väinade nimed Pisike silm ning Suur silm on moodustatud sama põhimõtte järgi nagu ka laidude nimed Kõrgelaid ja Madallaid. Analoogia juures on oluline see, et lingvistiline kogukond aktsepteerib moodustatavat nime. Selleks on vaja täita kaks tingimust. Esiteks, nime sisu peab olema tunnustatud koha identifitseerimiseks sobilikuna. Teiseks, nime kuju peab olema vastavuses kohalike onomastiliste tavadega: see peab olema nimi, mitte apellatiivne kirjeldus, mis juhtumisi identifitseerib koha. Nii saab pidada kohanimedeks ka ees- ja tagasõnu sisaldavaid nimesid Eerutoatagune, Laasutoatagune (põllud), Kambriots (aiamaa), Küinideesine, Kordisilmaesine, Kordipealne (heinamaad), Metsatagune (rannaäär) ja Männikualune (põld), sest nad viitavad püsivalt mingile kindlale kohale ja on üks nimekasutajate aktsepteeritud nimetamismallidest. Hoolimata analoogia olulisusest, hõlmab nimetamine alati ka mingi osa uut informatsiooni (Leino 2007: 31-32).

Mida rohkem inimesi nime kasutab, seda suurem on tõenäosus, et see jääb kestma, sest nimi elab vaid oma kasutajate kaudu.

\subsection{Kohanimede muutumine ja kadumine}

Nimi muutub, kui eelnevalt kasutatu hääbub ja selle asemel võetakse omaks uus nimi. Erinevalt säilinud nimest erineb muutunud nimi alati eelmisest sama kohta märkinud nimest. Muutuste protsess algab siis, kui uus nimi ilmub vana kõrvale, ja lõpeb siis, kui vana nimi on unustatud või seda peetakse endiseks nimeks (Ainiala 1997b: 109). Vana ja uue nime leksikaalne (apellatiivne) tähendus erinevad teineteisest. Kui aga nimi muutub vaid foneetilise struktuuri poolest, siis pole küsimus kohanime muutumises (Ainiala 2002b: 932). 1787. aastal kirjutatud kaardil on Kirge Nieth, 1933. aasta kogus Kerguniit ning tänapäeval kirjakeelseks muutunud Kirikuniit - kuigi nimes on toimunud keelelisi muutusi, on leksikaalne tähendus jäänud samaks. Samuti on nii praeguse Talila külaga, mille sufiksis -la kajastub veel kunagine saarelisus, 1787. aasta kaardil on külanimi Tallilaid, 1933. aasta kogu järgi on kasutusel mitu varianti - Talila Talilaid Talilao küla -, millest praeguseks on kasutusele jäänud vaid Talila. 1787. aasta kaardil on aga 
veel laiuna Eon Laidi, millest 1933. aastaks on saanud osa maismaast ning nimeks Äolaid, rööpnimega Laolaid, kajastades selles põllunimes veel endist saarelisust. Seal asusid 1933. aastal ka kaks talu Uusäola ja Vanaäola, millest tänaseks on saanud üks Äola talu.

Kohanimi kaob või asendub uuega, kui pole enam piisavalt põhjust kohta endistviisi nimetada. Selleks võib anda tõuke koha enese muutumine või hävimine, mingi märkimisväärne sündmus või elulaadi muutumine. Olulisteks teguriteks on seejuures ajaloo kulg ning looduslikud olud. Ühiskondlikud olud võivad jätta mõne koha nimetamisvajaduseta ning esile kergitada uued, looduslikud olud aga võivad muuta koha liiki (laiust saab madalik, heinamaast mets jne). Muutused toimuvad harva järsku. Peaaegu igal juhul muutuvad nimed aste-astmelt. Mõnda aega on kasutusel nii uus kui ka vana nimi ning uus nimi asendab vana tasapisi. Nii uus kui ka vana nimi võivad olla kasutusel paralleelselt. Nime muutus ja parallelism on omavahel tihedalt seotud ning alati ei ole neid kahte võimalik eristada. Enamikul juhtudest nõuab kohanime muutus rööpnimesid, samal ajal kui parallelism ei vii alati kohanime muutumiseni. Kohal võib olla korraga kaks või isegi enam nime. Rööpnimedel on tavaliselt erinevad kasutajad (Ainiala 2002b: 931, 933-934). Näiteks 1933. aasta materjali järgi on Madallaiul rööpnimi Põõsaga laid, seejuures viimane on sagedasem. Tänapäevaks on alles on jäänud vaid Madallaid. Talu ametlik nimi Ojakalda oli 1933. aastal kasutusel paralleelselt peremehe nimega Ligi, mis oli tollal põhiliseks talunimeks, tänaseks on jäänud alles vaid Ojakalda nimi. Vaadeldaval alal ongi suurem osa rööpnimedest talunimed. Seda saab seletada sageli vana peremehe surmaga, nii et kadus vajadus talu tema järgi nimetada (vt Ligi talu näidet), ning uute elanikega, kes toovad kaasa oma eelmise elukoha nime või tõrjuvad kasutuselt või võtavad taas käibele ametliku nime. Näiteks oli 1933. aastal Pao talul ametliku nime kõrval paralleelselt kasutusel omaniku järgi Kaiga-Miina nimi, millele lisaks tekkisid ka nimed Pärna-Miina ning Pärna (hoovis kasvava kahe pärna järgi), ning Pärna ja Pärna-Miina muutusid aja jooksul domineerivaks.

Nimi võib muutuda nii, et vana nimi kaob ja koht saab uue nime peaaegu samal ajal või vähemalt üsna kohe. Selline muutumine pole siiski eriti sage. Kui muutub kogukond, kes nime kasutab, siis on loomulik, et ka nimi muutub. Kui uutel elanikel ei ole võimalik õppida kohanimesid endistelt elanikelt, siis annavad nad kohtadele uued nimed.

Kõik nimed võivad muutuda, kuid praktikas seda siiski ette ei tule. Tõenäolisemalt muutuvad nimed, mis tähistavad väiksemaid kohti, ning need, millel on vaid mõni kasutaja. Algselt kirjeldab iga nimi oma referenti, kuid kui aja möödudes enam ei kirjelda, ei tähenda see tingimata, et nimi muutuks. Nime kõige olulisem funktsioon on kohta identifitseerida, mitte iseloomustada ning seda juhtub pigem harva, et vana nimi, mis enam oma referenti ei kirjelda, asendatakse uuega, mis kohta paremini kirjeldab (vt nt Pao Kaiga-Miina > Pärna-Miina Pärna talu). Oma referentide kirjeldamise saavad nimed lõpetada siis, kui koht ise mingil moel muutub. Näiteks uus hoone, uus kasutaja, omanik või muu taoline kohaga seotu, mis võib jätta nii tugeva jälje, et see nõuab uut, informatiivsemat nime. Ja kui kohal oli ka varem mingi nimi olemas, siis tavaliselt peab vana nimi uuele teed andma (Ainiala 2002b: 931-934). 1787. aastal kandis suur põld nime Wande Metza 
Pöld, tähistades enam-vähem sama ala nagu tänapäeva Tributsi männik. 1933. aastal oli aga see jaotatud paljudeks väikesteks maatükkideks, kuhu jääb nii metsa (Ula mets), põlde (Suuregipõld, mille osad on Vandemetsa põld, Leepõllud, Mäepõllud) kui ka karjamaid (Vandemetsa karjamaa, Kadarik). Sellele alale istutati 1938. aastal männik, mis kandis algul nime Ula-Talila mets. Seoses Teise maailmasõja ajal seal männikus toimunud lahingutega andis rahvas sellele Balti laevastiku juhataja viitseadmirali V. Tributsi järgi uue nime Tributsi männik. See näide ilmestab suurepäraselt, kuidas maastiku muutus ning tähelepanuväärne sündmus võivad kohanime muuta. Sealhulgas võivad nimed jääda samaks, kuid ala suurus võib muutuda: 1787 . aastal tähistas Wande Metza Pöld umbes poole suuremat ala kui 1933. aasta Vandemetsa põld ning maastiku muutumisega on nimi tänapäevaks täiesti kadunud (Alas 2008a: 40). Kohanime muutumiseks ei peagi olema absoluutset põhjust. Nimekasutajad ja vajadus identifitseerida on jäänud samaks ning vana ja väljakujunenud nimi oleks võinud endiselt kohta märkida, kuid nimi muutub ikkagi, sest inimesed tahavad rääkida ja meelde tuletada, mis on kohaga juhtunud või mis seal on või kelle oma see on. Eelmine nimi, mis ei kirjelda kohta loomulikult, jäetakse seetõttu kõrvale (Ainiala 2002a: 934-935; Ainiala 2002b: 186-187; Ainiala 2000: 31-39). Nii on saanud Rannapõllust Tooma põld ning Keskmisest põllust Aadu põld, nime muutumise põhjust võib oletada soovist näidata maa kuuluvust talule.

Mikrotoponüümide püsimisel on suur osa suulisel pärimusel, millele on aga omane muutumine ja varieerumine. Üks muutumise põhjusi on referendi asukoha nihkumine. Tavaliselt on tegemist väikese liikumisega ühe kohanimekoosluse piires. Näiteks tähistas 1933. aastal Pätakalaid poolsaart, Arjulahe kalda teispoolset äärt, nüüd aga märgib see laidu, mis jääb Arjulahe sisse. Samuti on ka kohaga, mis kannab nime Põlend väli: 1933. aastal jäi see maanteest põhja, tänapäeval aga jääb lõunasse.

Sama nimi erinevas kohas on kaks erinevat nime (Andersson 1993: 7). Et toponüümid on monoreferentsed, tähistab iga kohanimi vaid üht kindlat kohta ning häälikuline kokkulangevus tähendab homonüümiat. Talude puhul on väga sage, et omanik ehitab uude kohta maja ning võtab kaasa ka endise nime. Nii on näiteks Mõhkse taluga, mille omanikud küüditati, ning kui nad tagasi tulid, kolisid elama teise külla ja nimi kandus üle uuele majale. Teise maailmasõja ajal põles maha Reedike talu ning omanikud ehitasid uue maja mõne kilomeetri kaugusele, talu nimeks sai taas Reedike. Siiski tuleb neid pidada eri nimedeks, sest asukoht on muutunud.

Kohanimed kaovad siis, kui neid ei ole enam vaja. Selleks on erinevaid põhjusi ning tihti hääbuvad nimed mitme teguri koosmõjul. Kadunud nimed moodustavad pideva joone, mille ühes otsas on täiesti kadunud nimed, mida ei suuda meenutada ükski külaelanik, ning teises otsas on nimed, mida küll üldiselt mäletatakse, kuid mida enam aktiivselt kohtade identifitseerimiseks ei kasutata. Nende kahe äärmuse vahel on terve hulk nimesid, mida mäletab üks või paar inimest, kuid mida keegi enam aktiivselt ei kasuta (Ainiala 1997b: 109-112). Referentide ja traditsioonide stabiilsus on ka kohanimede püsimise eeldus. Terhi Ainiala järgi on Soomes võrreldes XVIII sajandiga enamikul aladest muutunud vähemalt $75 \%$ nimedest, mõnel alal isegi 90-100 \% (Ainiala 2002a: 186). Pöide vallas on see protsent umbes sama, läbi kolme sajandi on säilinud $18 \%$ nimedest. 
Vanade nimede muutumise ja hävimise põhjuseks on tavaliselt keelevälised tegurid: muudatused ühiskonnaelus, vanade elutavade hääbumine, nimeobjektide tekkimine või kadumine muudel põhjustel, eriti aga asustuse koondumine (Simm 1971: 688; 1976: 556). XIX sajandisse jääb krunditalude teke, mis tõi kaasa suure hulga nimede muutumise. Kui Teises maailmasõjas hävis terve Kübassaare asundusküla, kadus suur hulk Kübassaare poolsaarel asuvaid kohanimesid. Ka sealseid talunimesid mäletavad vaid üksikud, täielikult on aga kadunud vähemtähtsate objektide nimed nagu näiteks Kadakavälja põld, Reimerand ja metsaosade nimed Kadakavälja ots ja Soarmiku mets.

Linnadesse siirdumine, mis sai alguse 1960. aastatel, viis selleni, et üha vähem inimesi tegeleb maaharimisega. Sellega väheneb ka nende nimedega seotud kommunikatsioon, mis on aga toponüümide olemasolu esmane tingimus. Mitme talu tühjaksjäämine samas piirkonnas võib tähendada suure hulga kohanimede kadumist (Ainiala 1997b: 112). Samuti pole olnud stabiilne kohtade endi areng: osa põllumaid ei kasutata enam, nad on asendunud metsaga, elumajade või maanteedega, on liidetud teiste suurte põllumaadega, mereäärsed karjamaad on kasvanud roogu jne ning sellega seoses on kadunud ka vajadus neid kohti eristada. Maa kasutamine on viimastel sajanditel palju muutunud, aidates kaasa kindlat tüüpi nimede hävimisele. Kui varem olid väikesed põllud eraldi, siis nüüdseks on põllud ühendatud ning tarad ja kraavid kadunud. Niisiis on vajalik nimetada vaid suurt põldu ja väikeste põlluosade nimed on kadunud ning inimesed saavad hakkama vähema arvu nimedega. Vajadus identifitseerida väikeseid kohti on kadunud, mistõttu vanu nimesid polegi uutega asendatud (Ainiala 1997b: 113). Nii oli näiteks 1933. aastal Nõudlamaa (heinamaa) jagatud veel eraldi osadeks Suurenõudla kuhjaaid, Taganõudla, Vältanõudla, Lõonõudla ja Nõudla arvad, praeguseks on kasutusel vaid ühine nimetaja Nõudla, nagu ka 1787. aasta kaardil on olemas vaid Naudla Maa.

Väga sageli jätab hävinud objekt ümbruskonna nimistusse oma jälje. Näiteks kunagise mõisa viinakeldri asukohale ehitati Viinakeldri talu, mis on samuti tänaseks hävinud. Endise talu ümbruses on aga uued nimed Viinakeldri aavik (metsatukk) ning Viinakeldri aed (karjakoppel), mis on kunagise mõisa viinakeldrist tulenevad sekundaarnimed. Kotka talu olevat aga oma nime saanud kunagise tamme järgi, mille otsas oli kotkapesa. XVIII sajandi kaardil on märgitud Töna talu, mida 1933. aastaks enam ei ole, kuid mille nime kandsid siis edasi kõrval asuva Töönapöld ja heinamaa Töönaauk, millest viimane on säilinud tänaseni. Talunimede säilimine pärast maja hävimist on seletatav ka sellega, et talu ei tähista üksnes maja, vaid tervet hoovi ning maja koos ümberkaudsete maadega. Nii on Muraja poolsaarel kasutusel siiani näiteks Mõhkse, Kaomäe ja Tagupõllu talude nimed, kuigi maju pole endiste talude kohal enam ammu. Põhjuseks võib olla ka muude silmapaistvate objektide puudumine läheduses. Vastupidine muutus toimub siis, kui talu hävib ning maa jääb naabertalule. Nii on näiteks Laaritsa taluga, mille hävimisega kadus kasutuselt ka nimi ning mille maad on nüüd osa toona kõrval asunud Laasu talust.

Kohanime kadumise hetke on võimatu paika panna. Kui aktiivselt peaks nime kasutatama, et see säiliks? On nimesid, mida kunagi ei kasutata iga päev, näiteks on kohad kaugel või piirkonnas, kus ei käida väga sageli. Kuid ka neid kohti on aeg-ajalt vaja nimetada. Nime võib pidada surnuks siis, kui 
seda ei saa enam kasutada, sest teised kogukonna liikmed ei tea seda. Nimi ei saa sõltuda ühest inimesest, sellel peab olema vähemalt kaks kasutajat. Kui on alles jäänud vaid üks inimene, kes seda nime teab, võib seda pidada kadunuks (Ainiala 1997b: 109).

\section{Kultuurnimede ja loodusnimede muutumise analüüs}

Nimed varieeruvad koha tüübist lähtuvalt erinevalt. Kohanimesid saab tüübi alusel jagada kultuurnimedeks ja loodusnimedeks. Kultuurnimede alla paigutuvad kõik nimed, mis tähistavad asustusi, viljelusobjekte ning artefakte kohti, kus kas või osaliselt on toimunud inimtegevuse tagajärjel muutusi. Loodusnimed tähistavad aga kohti, mis seotud maastiku ja vetega. Viljelusnimed kipuvad muutuma sagedamini kui loodusnimed, sest loodusesemed on juba oma loomult püsivamad.

Loodusesemete nimede puhul on olulisim asukoht, aga ka koha kuju ja suurus. Kultuurnimede puhul on samuti olulisim asukoht, kuid nimetamise aluseks on ka koha päritolu, saamislugu ja koha omanik. Samuti liigenduvad loodusesemed maastiku, põllumajandusnimed aga kasutusala järgi. Selline otseselt inimtegevusest mõjutatud või inimtegevuse tagajärjel tekkinud kohtade ning looduses iseseisvalt eksisteerivate kohtade nimede eristamine on tingitud nende referentide ning seega ka neid tähistavate nimede erinevast säilimisest. Objekti stabiilsus on aga püsiva traditsiooni kõrval teine oluline tingimus, et nimi jääks püsima. Kui nime tunnevad ja selle on heaks kiitnud paljud inimesed, siis see ka ei muutu nii kergelt. Tavaliselt on viljelusnimed loonud väike kogukond ning nimede eesmärk pole eristada kohta suurel alal, vaid pigem talus (Ainiala 1997a: 234, 238; 2002a: 183-184; 2002b: 933; Harling-Kranck 2002: 191). Loomulikult on sellises inimtegevusest mõjutatud jaotuses ka piiripealseid juhtumeid, sest metsa võib istutada või langetada, jõgede ette võib

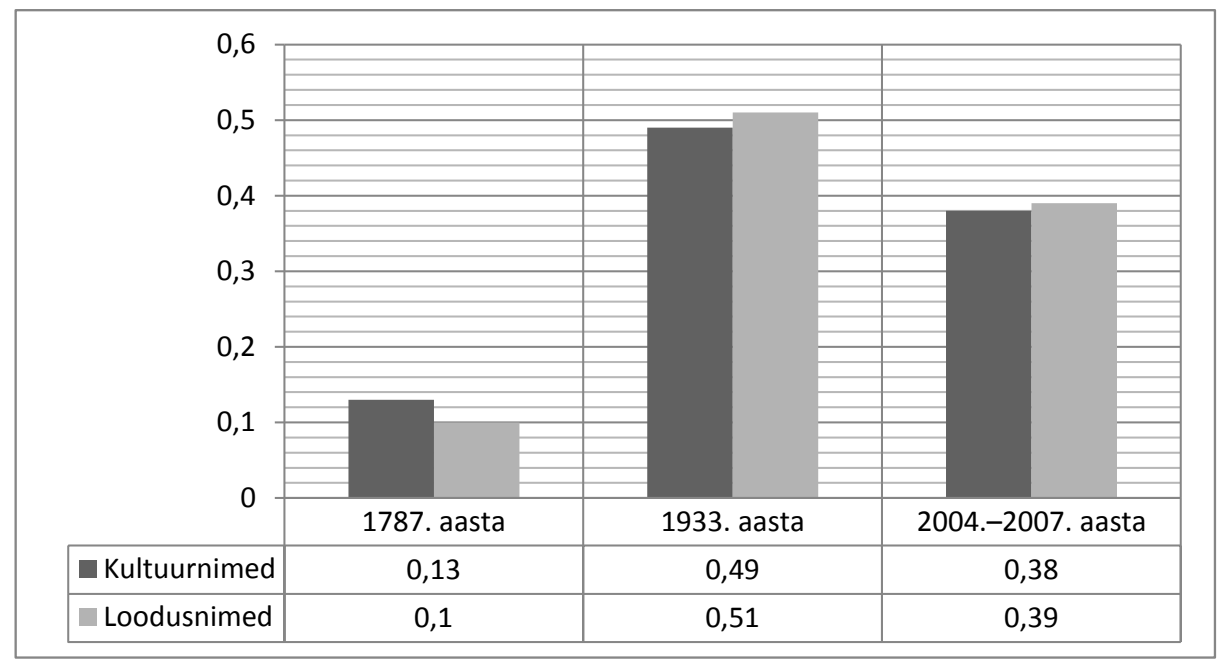

J o o n i s 1 . Kultuur- ja loodusnimede osakaal. 


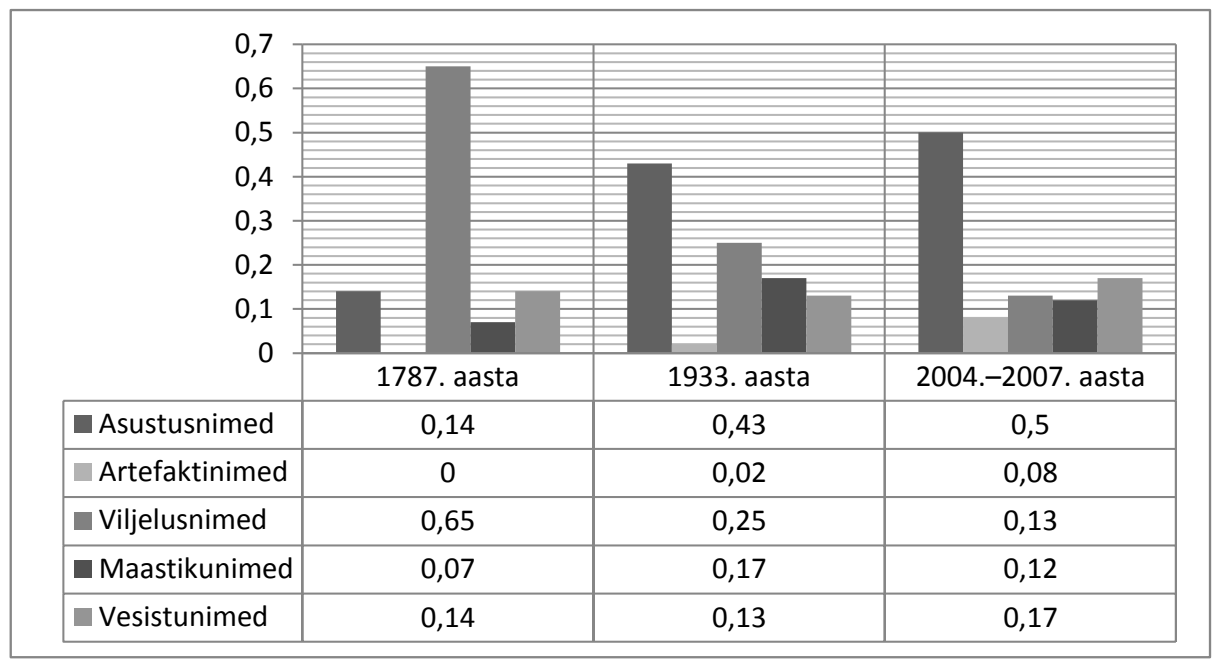

J o o n i s 2. Kohanimede jaotumine ajajärguti.

ehitada tammi, mistõttu vesi võib hakata läbi voolama mujalt, jne, kuid ka sellisel juhul peetakse metsa ja jõge ikkagi loodusobjektiks.

Kultuurnimede ja loodusnimede osakaalu erinevatel ajajärkudel näitab joonis 1. Sellest nähtub, et kultuurnimesid on nii 1933. kui ka 2007. aastal veidi vähem, 1787. aastal aga rohkem. Võib arvata, et ka XVIII sajandi lõpus olid loodusnimed ülekaalus, kuid kaardimaterjal lihtsalt ei näita seda, sest aluseks olnud atlase eesmärk on tähistada põllumajandusega seotud objekte ja loodusesemete nimesid on esitatud vaid kõlvikute asukoha määramiseks.

Joonisel 2 on näha erinevate nimeliikide esinemisprotsendid ajajärguti. Samuti näitab joonis, mis liiki kohad on olnud eri aegadel nimekasutajatele olulisemad. 1787. aasta protsentide puhul tuleb aga arvestada ka atlase eesmärki panna kirja kõlvikud, mille asukohta külade, mõisate ja hajatalude abil näidata.

\subsection{Kultuurnimed}

Kultuurnimede tähtsamad alaliigid on asustusnimed ja viljelusnimed, kolmas - tehisobjektide nimed - on marginaalsem ega moodusta terviklikku rühma (olulisemana saab välja tuua teenimed). Asustusnimede alla kuuluvad inimese elupaika tähistavad nimed, näiteks külade (vt ka Alas 2009a) ja talude nimed. Viljelusesemete nimedeks peetakse heinamaa-, põllumaa- ja karjamaanimesid. Kui asustusnimed on väga püsivad, siis viljelusnimede kohta seda öelda ei saa. Nagu mainitud, kasutab viljelusnimesid väiksem kogukond ning nimede eesmärk pole eristada kohta suurel alal, vaid pigem ühe talu piires.

Kui suur osa põllumajanduslikke nimesid on mikrotoponüümid ja nimede kasutajaskond on väikesearvuline, siis looduslike kohtade nimesid teab tavaliselt suurem hulk inimesi, sest looduslikud kohad pole niivõrd sõltuvuses omandisuhetest, vaid on avatud rohkematele inimestele. Näiteks on tarvidus põllu osi eraldi nimetada põllu omanikul ehk kasutajal, kellelgi väljastpoolt talu seda 
vajadust ei teki. Samuti kajastatakse põllumajanduslikes nimedes sageli omandisuhet, omaniku vahetudes või maa kasutamise muutudes ei jää ka nimed samaks. Näiteks kandis heinamaa XVIII sajandi lõpu kaardi järgi nime Uus Nieth, mis põllumaana oli saanud 1933. aastaks nime Leepõld, ning tänapäeval nimetakse seda kohta hoopis talude järgi Mihkli ja Matsi põldudeks.

Kuigi suurem osa viljelusnimedest on mikrotoponüümid, mida kasutab vähe inimesi ja millel on seega kalduvus kaduda, on osa agraarnimedest makrotoponüümid ning seetõttu ka hästi säilinud. Kõige paremini jäävad püsima need viljelusnimed, millel on mitu omanikku või kasutajat. Näiteks on maanteede ristumiskohaäärne Surnuaiatagune põld teada mitme küla elanikele, samuti ka Linnapöllud, mis jäävad kahe küla vahele ning mille nimi on säilinud sajandeid.

Suur osa kultuurnimedest on aga asustusnimed, mis on vastupidiselt viljelusnimedele väga püsivad. Näiteks külanimed Kõrkvere [1453 Korckever (Kallasmaa 1996: 144)] ja Keskvere [1645 Kesckfer (Kallasmaa 1996: 97)] on jäänud sama kujuga sadadeks aastateks nagu ka suurem osa Pöide valla asulanimedest. Külanimedest on muutunud vaid mõningad determinandid. Näiteks on kadunud maareformide käigus endise mõisa maadele rajatud asundusküla ehk asundi mõiste ning see on asendunud determinandiga küla: Muraja asund $\rightarrow$ Muraja küla. Üldjuhul kasutatakse elliptilist vormi Mura$j a$, liigisõna lisatakse vaid erivajadusel. Kõikidest vaadeldava ala kultuurnimedest poole moodustavadki asustusnimed, eelkõige talunimed. ${ }^{3}$ Inimeste kodud on oluline osa maastikul ning nende nimed ei hävi nii kergesti, külade ja talude nimed on teada laiale kasutajaskonnale. Igal talul on oma nimi, mis põlistaludel on säilinud sajandeid. Näiteks talud Koka [1617 Matz Kockh (Kallasmaa 1996: 114)], Kelbi [1730 Kelbi Otti Matz (Kallasmaa 1996: 94)], Lõo [1738 Leo Reino Michel (Kallasmaa 1996: 195)] ja Pojandi [1738 Poyande Thomas (Kallasmaa 1996: 297)].

Kultuurnimede jaotumist näitab joonis 3 .

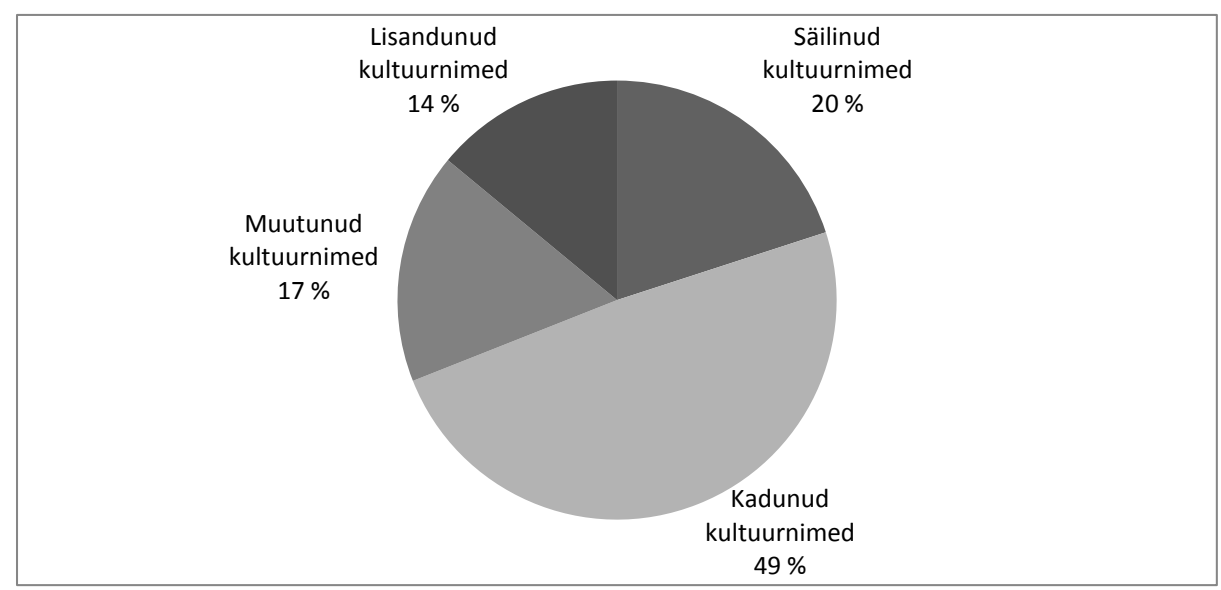

J o o n i s 3. Kultuurnimede jaotumine.

${ }^{3}$ Kogu Pöide nimevarast moodustavad asustusnimed kolmandiku, aga Võrumaal poole, Soomes vaid $22 \%$ (Saar 2008: 67). 
Kultuurnimedest suurim rühm on kadunud nimed, mida on $49 \%$. See protsent on võrreldes hävinenud loodusnimedega väiksem, mis on tingitud säilinud talunimede suurest hulgast. Nimede kujunemises ja püsimises on suureks mõjutajaks uute põllumajanduslike süsteemide kasutuselevõtt, sest selle käigus muudetakse senist maastikku. Samuti on suur osa nimesid kadunud põllumajanduse osatähtsuse vähenemise tõttu. Kultuurnimedest on säilinud viljelusnimesid läbi kolme sajandi vaid kaks protsenti. Kadunud on endiste ühispõldude ja nende osade nimesid. Ka karjamaa- ja heinamaaosade nimede hulk on vähenenud, sest on kahanenud vajadus neid eraldi nimetada. Üksiktaludes on karjakasvatamine tunduvalt vähenenud, kariloomi peavad enamasti ühistud. Nii on heina- ja karjamaid kasutavate inimeste arv endisest kordades väiksem ning seega vajadus nendele kohtadele viidata vähenenud. Näiteks on tänaseni säilinud Jausapõllu nimi, kuid 1933. aasta materjalis esitatud põlluosade nimesid (Keskmine põld, Suurpõld, Vanatänava põld) enam ei mäletata.

Artefaktide nimedest on enim lisandunud aga teenimesid: $78 \%$ teenimedest on uued. Põhjuseks võib olla inimeste suurem liikuvus, samu teid kasutavate inimeste hulk on suurenenud. Hävinud on varasemad väikesed teed ja rajad, mille kasutajaid ning ühtlasi ka nime kasutajaid on vähem. Väiksemad teed on asendunud suurtega, mis on rajatud põhiliselt nõukogude ajal. Näiteks nimetatakse kolhoosiajal rajatud teed Suureks teeks ning endised vankriteed Keskmine tee ja Lai tee on hääbunud koos oma nimedega.

\subsection{Loodusnimed}

Loodusnimesid kasutavad paljud inimesed ning suulist pärimust on seega raskem katkestada. Suuremate kesksete looduslike kohtade nimed on kõigest hoolimata hästi säilinud ning mõnikord äärmiselt vanad. Jooniselt 4 on näha, et loodusnimede jaotumine on üsna sarnane kultuurnimede omaga. Sarnaselt kultuurnimedega moodustavad ka loodusnimedest enamuse kadunud nimed (51\%) ning enam-vähem võrdselt on lisandunud, säilinud või muutunud nimesid.

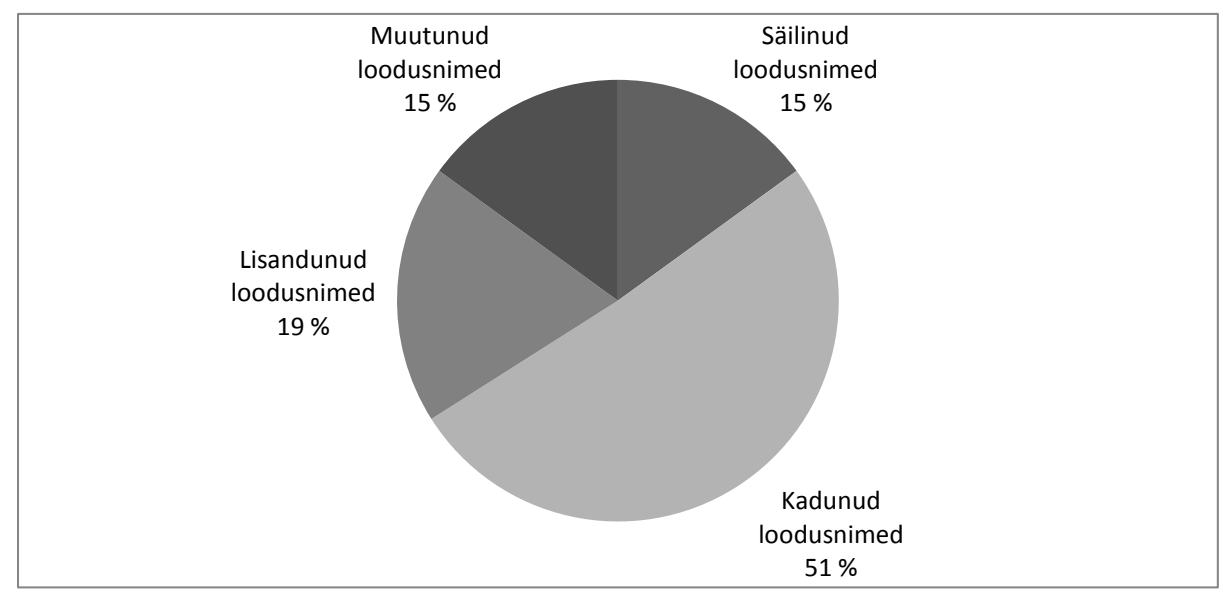

J o o n i s 4. Loodusnimede jaotumine. 
Oronüümid (pinnavormide nimed) on üks suuremaid nimekorpusi talunimede kõrval, moodustades maastikke tähistavatest nimedest tugevalt üle poole $(61 \%)$. Aga kuigi mäed on looduses väga püsivad, on mäenimedest säilinud vaid $15 \%$. Põhjus võib olla jällegi eluviisi muutuses. Näiteks ei ole kunagistele väikestele teedele jäänud kõrgemaid kohti enam vaja tähistada ning koos teedega on ununenud ka sealsed maastikumärgid. Samuti on osa oronüüme kadunud seoses viljelusesemete osade eristamise vajaduse vähenemisega, nimelt nähtub 1933. aasta materjalist, et mäenimede abil tähistati ka põllumajanduslike kohtade osi. Nii ongi tänaseks kadunud tervelt kolmveerand mäenimedest. Läbi kolme ajajärgu on püsinud vaid üks mäenimi Ainemägi.

Vetenimedest või nendega seotud nimedest on enim poolsaarenimesid ja nende arv on suurenenud varasemate saarte arvelt. Näiteks 1787 . aastal veel laid olnud Kibbasaar on 1933. aastaks muutunud poolsaareks - Kübassaare poolsaar -, kus loodusobjekti liigi muutumisega on endine liigisõna nihkunud atribuudi osaks ning lisandunud on uus determinant poolsaar. Nimi on niisugusena kasutusel ka tänapäeval. Rannaäärte kinnikasvamisega ning raskemini läbitavateks muutumisega, aga ka maa kerkimisega laidudest poolsaarteks on tänaseks kadunud $49 \%$ rannajooneobjektide nimedest.

Kui võrrelda nimesid, mis on olemas nii 1933. kui ka 2007. aastal, on loodusnimedest säilinud $13 \%$, kultuurnimedest on jäänud samaks mõnevõrra enam: $19 \%$. Suureks mõjutajaks on aga talunimed, mis moodustavad väga suure osa kultuurnimedest (1865 kultuurnimest on elupaika tähistavaid nimesid 914): asustusnimed on väga püsivad ning lisavad seega kultuurnimede jaotusele stabiilsust. Kui aga talunimed loetelust eraldada, on kultuurnimedest 1933. ja 2007. aastal samad vaid $4 \%$, mis kinnitab, et viljelusnimede püsivus on loodusnimede omast väikesem.

Kuigi diagrammid näitavad, et kõikidest nimedest on ligikaudu pool kadunud, on terve hulk tänaseks muutunud nimesid kas osaliselt või täielikult säilinud atribuutosaga, vahetunud võib olla determinant või osa sellest. Näiteks poolsaart, mis 1787. aastal kandis nime Kordi Saar, nimetatakse 1933. aastal nimega Kordimaa ning tänapäeval Kordisäär, nii et veel kord on vahetanud liigisõna. Nimede muutumine võibki toimuda nimesiseste varieerumiste kaudu (näiteks tänapäevane Oitme niit kandis 1933. aastal nime Oitme karjamaa ning 1787. aastal Oitmi Rand) või leksikaalsel alusel, kus koht saab mingil põhjusel täiesti uue nime (näiteks 1787. aastal Sarrapicko Pöld, 1933. aastal Kõrgaapõld ning 2007. aastal Mardi põld).

Vaatluse all olevast materjalist ilmneb ka, et lisandunud nimed ei ole sageli moodustatud apellatiividest, vaid varasemate nimede põhjal. Näiteks pole külaosanimi Kadarikumehed saadud apellatiivist kadarik, vaid see on sekundaarnimi põllunimest Kaddaricke und Werni Pöllut, mis on esitatud sellisel kujul 1787. aasta kaardil ning tähistab ala, kuhu hiljem talud rajati.

\section{Kokkuvõte}

Kokkuvõtteks saab öelda, et kunagistest nimedest on kadunud umbes pool ning et seejuures on võrdselt kadunud nii loodus- kui ka kultuurnimesid. Erinevuseks võib aga pidada, et kui kultuuresemeid tähistavates nimedes on toimunud muutused pigem täielikud, siis loodusnimedes on tegemist osalise 
varieerumisega: muutunud on determinant või osa atribuudist. Peamiste mõjutajatena saab välja tuua ühiskonnaelu muudatused, ajaloo kulu (ümberkorraldused põllumajanduses, linnastumine, asustuse koondumine jm eluviisidega seotud muutused), aga ka looduslikud olud (mereääred on muutumas raskemini läbitavateks, maapinna kerkides ühinevad laiud maaga poolsaarteks jne). Üldiselt saab aga öelda, et vaadeldava ala kohanimed on olnud püsivad, kuigi tendentsiks on nimede vähenemine ning nende kirjakeelsemaks muutumine. Pöide valla asustus on olnud järjepidev, seda kinnitavad ka kohanimed, mis on säilinud tänaseni. Vaadeldaval alal ei saa välja tuua ühtegi piirkonda, millest poleks tänaseni säilinud ainsatki nime. See, et nüüdseks on alates XVIII sajandi lõpust hävinud ligikaudu $50 \%$ nimedest, näitab pigem Pöide ala kohanimede elujõulisust ning jätkusuutlikkust.

\section{Kirjandus}

A in i a la, Terhi 1997a. Muuttuva paikannimistö. (Suomalaisen Kirjallisuuden Seuran toimituksia 667.) Helsinki: Suomalaisen Kirjallisuuden Seura.

A in i a l a, Terhi 1997b. On Perpetuation, Demise and Change in Place Names. You Name It. Perspectives on Onomastic Research. Toim Ritva Liisa Pitkänen ja Kaija Mallat. (Studia Fennica. Linguistica 7.) Helsinki: Suomalaisen Kirjallisuuden Seura, lk 106-115.

A i n i a l a, Terhi 2002a. Finnish Names of Cultivated Lands. - Onoma, nr 37, lk 181-188.

A in i a la, Terhi 2002b. Why Do Place Names Change? - Actas do XX Congreso Internacional de Ciencias Onomàsticas. Santiago de Compostela, 20-25 setembro 1999. Toim A. I. Boullón Agrelo. Santiago de Compostela: A Coruña, lk 931-935.

Alas, Marit 2008a. Kohanime muutumine kui nimekasutaja vajadus. - Oma Keel, nr 1, lk 37-43.

A la s, Marit 2008b. Kohanimede muutumine Pöide vallas Saaremaal. Magistritöö. Tallinn. (Käsikiri Tallinna Ülikooli Eesti Keele ja Kirjanduse Instituudis.)

A l a s, Marit 2009a. Asulanimede muutumisest Pöide vallas Saaremaal. - Noored filoloogid. Emakeelepäev täis tarkuseteri. Toim Anastassia Zabrodskaja. Tallinn: Tallinna Ülikooli Kirjastus, lk 40-61.

A l a s, Marit 2009b. Change of Cultural and Nature Names in Pöide Parish (Saaremaa, Estonia). - Names in Multilingual, Multi-Cultural and Multi-Ethnic Contact. Proceedings of the 23rd International Congress of Onomastic Sciences. August 17-22 2009. York University, Toronto, Canada. Toim. Wolfgang Ahrens, Sheila Embleton, André Lapierre. Toronto: York University, lk 76-85.

A l a s, Marit 2009c. Kohanimede muutumine Pöide vallas Saaremaal. - Tallinna Ülikooli üliõpilaste 2007/2008. õppeaasta parimad teadustööd. Toim Leelo Ansaar. Tallinn: Tallinna Ülikooli Kirjastus, lk 68-73.

A n d e r s s o n, Thorsten 1993. Ortnamnens existentiella vilkor. - Ortnamn varda att vårda. Föredrag från Riksantikvarieämbetets symposium Ortnamnskultur. Stockholm 5-7 maj 1993. Red. Göran Ulfsparre. Stockholm, lk 7-19.

C h r i s t o p h, Ernst-Michael 1990. On Name Systems in the Communication of a Village Community. - Proceedings of the XVIIth International Congress of Onomastic Sciences. Helsinki 13-18 August 1990. Vol. 1. Toim Eeva Maria Närhi. Helsinki, lk 232-239. 
D a l b e r g, Vibeke 2008. The Psychology of Place-Name Changes. - Name and Place. Ten Essays on the Dynamics of Place-Names. Toim Gillian Fellows-Jensen, Peder Gammeltoft, Bent Jørgensen, Berit Sandnes. København: Københavns Universitet, lk 50-60.

$\mathrm{H}$ a r l i n g - K r a n c k, Gunilla 2002. Finland-Swedish Names of Fields, Meadows and Pastures. - Onoma, nr 37, lk 189-193.

K a ll a s m a a, Marja 1996. Saaremaa kohanimed I. Toim Helmi Neetar. Tallinn: Eesti Keele Instituut.

K a ll a s m a a, Marja 2000. Kimbuke terminnimesid Saaremaalt ja Lääne-Eestist. - Inter dialectos nominaque. Pühendusteos Mari Mustale 11. novembril 2000. Koost ja toim Jüri Viikberg. (Eesti Keele Instituudi toimetised 7.) Tallinn: Eesti Keele Sihtasutus, lk 73-86.

Ki vi n i e mi, Eero 1990. Perustietoa paikannimistä. (Suomi 149.) Helsinki: Suomalaisen Kirjallisuuden Seura.

Le in o, Antti 2007. On Toponymic Constructions as an Alternative to Naming Patterns in Describing Finnish Lake Names. (Studia Fennica. Linguistica 13.) Helsinki: Suomalaisen Kirjallisuuden Seura.

N is s ilä, Viljo 1962. Suomalaista nimistöntutkimusta. (Suomalaisen Kirjallisuuden Seuran toimituksia 272.) Helsinki: Suomalaisen Kirjallisuuden Seura.

$\mathrm{S}$ a a r, Evar 2008. Võrumaa kohanimede analüüs enamlevinud nimeosade põhjal ja traditsioonilise kogukonna nimesüsteem. Tartu: Tartu Ülikooli Kirjastus.

S i m m, Jaak 1971. Võnnu asulanimede vahetumine ja hävi. - Keel ja Kirjandus, nr 9, lk 686-688.

S i m m, Jaak 1976. Igal kohal oma nimi. - Keel ja Kirjandus, nr 8, lk 556-557.

\section{Change of Place Names in Pöide Parish}

Keywords: place names, change of place names, onomastics, toponymics, dialectology, socio-onomastics

The article reports a study of changes in place names used in Pöide parish, focussing on three time periods from the end of the 18th century until today. The necessity for place names depends on people's need to communicate and identify a certain place, while survival of the names critically depends on their use. Both social changes and changes in nature may be the reason for changes in place names. Place names can be classified into cultural and nature names. This classification is expedient, because the names change differently as do their referents. Although nearly half of the names of either group have not survived, the changes observed across the groups are different. Cultural names tend to be subject to total lexical replacement, whereas nature names are rather replaced partly, change affecting either the determinative or a part of the attribute.

Marit Alas (b. 1983), MA, Institute of the Estonian Language, Assistant, marit.alas@eki.ee 